\title{
Stillborn Banking Union: \\ Explaining Ineffective European Union Bank Resolution Rules
}

\author{
Ioannis Asimakopolous, University of Luxembourg \\ David Howarth, University of Luxembourg
}

This is an authors' pre-print version. Please reference the final published version:

Asimakopolous, I. and Howarth, D. (2021) 'Stillborn Banking Union: Explaining Ineffective European Union Bank Resolution Rules', Journal of Common Market Studies, Early View, DOI: 10.1111/jcms.13212

\begin{abstract}
Our contribution demonstrates and explains the ineffectiveness of European Union (EU) bank resolution rules, a core element of Banking Union. This inadequacy owes in large part to the limited access to and insufficient availability of EU resolution funds and inadequate national deposit guarantee schemes in most EU member states, in conjunction with the relatively high minimum requirements for own funds and eligible liabilities (MREL) for many EU banks. In many cases, these requirements are unlikely ever to be met - particularly for retail banks most likely to require resolution in the euro periphery. We offer a liberal intergovernmentalist analysis to explain the inadequacy of the EU resolution regime by examining German and French government preferences on EU rules on bank capital requirements agreed earlier in 2013 and national deposit guarantee schemes agreed in 2014. These government preferences were shaped significantly by the preferences of national banks and bank associations.
\end{abstract}

Keywords: Banking Union, Single Resolution Mechanism, Bank Recovery and Resolution Directive, deposit guarantee schemes, MREL (minimum requirements for own funds and eligible liabilities) 


\section{Introduction}

Effective bank resolution rules serve a dual purpose in European Banking Union: they enhance financial stability and break the sovereign-bank debt loop. On the first, the internalization of losses in resolution instead of relying on bail-outs by governments leads to a fairer risk pricing of bank liabilities and ultimately enhances market discipline and financial stability. On the second, minimizing the need for bail-outs decreases the likelihood of host member states suffering from a debt crisis because of the need to rescue banks. The Single Resolution Mechanism is thus one of the three main pillars of Banking Union, including single supervision and deposit insurance, supported by a financial backstop and underpinned by the single rulebook for banking, which includes harmonised resolution rules in the Bank Recovery and Resolution Directive.

In 2014, EU member state governments agreed upon the main element of the European Union's (EU) bank resolution rules — the Bank Recovery and Resolution Directive and the main element of the resolution regime that applies only to Banking Union countries - the Single Resolution Mechanism Regulation. We refer to the similar rules included in both the directive and the regulation as the EU bank resolution regime. The member state governments agreed that new rules were to be applied to nearly all — with few exceptions — of Europe's banks — both 'significant' and 'less significant' (SSMR, Article 4) — and that 'public interest' (BRRD, Article 32(5); SRMR, Article 18(5)) was sufficient to justify the use of the bail-in tool (interview 12) through which private shareand debt-holders were expected to assume some losses before resolution funds and the public sector provided financial support. 
However, since the launch of Banking Union, the European-level resolution authority, the Single Resolution Board ('Board') appears to have interpreted 'public interest' narrowly, leading to the conceptual paradox that even 'significant' banks enter liquidation where the use of public funds with lower and more flexible bail-in preconditions are used to mitigate financial stability concerns. This reassessment of the application of EU rules indicates the lack of a credible resolution framework that would allow the Single Resolution Board to comply with its 'public interest' mandate (Stiefmüller, 2016). Ultimately, this reassessment reflects the ineffectiveness of the EU resolution regime and thus a major lacuna in Banking Union more generally — by pushing the management of many insolvent banks back to the national sphere to be determined by the vagaries of national politics.

This ineffectiveness is illustrated by the experience with EU bank resolution since 2014. Only one out of six banks under the Single Resolution Board's remit facing solvency problems ended up in resolution, namely Banco Popular Español (Popular). Popular was sold to Santander for one euro, while part of the losses was covered through a bail-in of shareholders and junior subordinated debtholders (Mesnard et al., 2017). Popular must be seen as highly exceptional. Had Santander not accepted to intervene, Popular's Portuguese subsidiary would have ended up in liquidation (interview 10). The banks in the other five cases - Monte Paschi di Siena, Veneto Banca and Banca Popolare di Vicenza, ABLV Luxembourg, and NordLB — avoided resolution (Asimakopoulos, 2018b). 
In this paper, we demonstrate and explain the ineffectiveness of EU bank resolution rules — especially vis-à-vis retail banks that rely on deposit funding (Ayadi, 2019) which comprise the very large majority of banks headquartered in the EU. In particular, we focus on those banks that are too small to liquidate under corporate insolvency rules and too large to have bail-inable buffers of high quantity and quality for resolution purposes which amounts to approximately 120 banks out of the EU's largest two hundred banks in terms of assets (Asimakopoulos, 2019a). This ineffectiveness owes in large part to the difficulty to access and the insufficient availability of resolution and deposit guarantee scheme funds in most EU member states in conjunction with the relatively high minimum requirements for own funds and eligible liabilities (MREL) for many EU banks, which in many cases are unlikely to ever be met — particularly for those banks most likely to require resolution in the Eurozone periphery (Asimakopoulos, 2019a). We in turn explain this regulatory architecture by examining German and French preferences on EU bank capital requirements, MREL — set in the Bank Recovery and Resolution Directive resolution financing and deposit guarantee schemes.

We argue that the antecedents of under-capitalized banks, combined with the absence of credible resolution financing, have resulted in a European bank resolution regime that is bound to fail. Market fragmentation and the lack of a true EU Capital Markets Union have resulted in many banks - especially in member states without deep financial markets — being unable to increase the amount or improve the quality of their MREL to ensure successful resolution according to EU rules. The inadequacy of MREL levels undermines the efficacy of the European bank resolution regime because for bail-in to be enforceable, banks need to have a sufficient level of capital, as well as a sufficient amount 
of 'eligible' liabilities to absorb losses. Without this capital and liabilities buffer (MREL) there is a greater risk of imposing losses on depositors or governments must pay to save or liquidate the bank. Large bail-ins affecting retail investors and depositors can be politically difficult for governments while bail-outs contribute to government debt and ultimately impose the costs of either saving or liquidating banks on tax-payers.

Our argument proceeds as follows. In the first section, we provide a review of the relevant existing literature on Banking Union, EU economic governance and EU resolution rules more specifically, and our analytical contribution to these bodies of literature. In the second section, we demonstrate that the MREL-based regulatory framework with limited collective industry funds is unlikely to support effectively either of the two resolution scenarios outlined in the EU resolution framework — that is, resolution based on openbank bail-in or on transfer strategies — and thus pushes banks into national liquidation and can then benefit from public funding. However, whilst inadequate MREL levels undermine the efficacy of EU resolution rules, adequate MREL levels might threaten the viability of retail banks due to their retail and low-risk business model (Asimakopoulos 2019a).

In the third section, we explain national preferences that resulted in this 'trap door' design by explaining national government preferences on capital requirements and MREL in terms of the preferences of nationally-headquartered banks and the structure of national banking systems. MREL requirements are not directly defined in the EU resolution framework and are set by the resolution authorities, yet they are designed to ensure the enforceability of bail-in to the extent required by the legislature. Therefore, as long as the 
legislature requires a fixed bail-in requirement before accessing resolution financing, resolution authorities need to draft the MREL policy accordingly. Capital requirements form part of the MREL requirements — while prudential capital comprises equity instruments and other instruments that qualify as own funds, MREL requirements can be met either with more equity or unsecured debt. The fixed bail-in requirements for all banks, as agreed in 2014, may lead to disproportionately high MREL requirements for the retail bank business model and reflects the efforts of a number of EU member state governments — led notably by the French and German governments — to force all banks that require resolution to be in a position to internalize losses entirely by issuing more eligible liabilities. Large universal banks — that can tap markets more easily — and small cooperative and savings banks - that do not qualify for resolution and hence do not require high MREL — are not severely affected by this approach. Instead, mid-sized retail banks that qualify for resolution - numerous in the EU periphery and in other countries that lack deep capital markets — are severely affected by this approach since the need to issue more MREL may threaten their viability. Setting the bail-in requirements at the same level for all banks and thus relatively high for retail banks reflects the powerful interests of national bank lobbies and was prioritized over policy developments that would both protect taxpayers and further European integration.

In the fourth section, we examine national government preferences on the revised Deposit Guarantee Scheme Directive agreed in 2014, the lack of a transfer mechanism among national deposit guarantee schemes and failure to create a European Deposit Insurance Scheme. Here we explain government preferences in terms of existing deposit guarantee schemes which in turn reflect both the preferences of nationally-headquartered banks and 
the structure of national banking systems. Methodologically, our analysis relies upon the triangulation of information gleaned from EU legislation and policy documents; comments on Basel Committee and EU Commission consultation documents; central bank, resolution fund and deposit guarantee fund data; a range of quality newspaper and secondary sources; resolution decisions to date; and interviews with twelve officials from central banks, the EU Commission, national ministries of finance officials and bank associations.

\section{Our analytical framework and contribution to the literature}

Our main research question is: how is the insufficiency of the core building blocks of an effective EU resolution regime best explained? Our answer to this question is driven by a liberal intergovernmentalist analysis: German and French government preferences on these building blocks — and specifically capital requirements, MREL, resolution and deposit guarantee funds - reflect the concerns of nationally-headquartered banks and bank associations. We would expect smaller independent banks to push for lower capital requirements and lower MREL given their lack of equity and their indifference to tighter European deposit guarantee scheme rules where they have well-funded pre-existing schemes. We would expect divergence in the position of bigger banks on capital requirements depending on system-wide structural factors and either reluctance or indifference to MREL. We would expect the opposition of big universal banks to the reinforcement of deposit guarantee schemes, especially in countries where these schemes have been underfunded. Liberal intergovernmentalism also predicts the limited delegation of policymaking powers on matters where micro-economic interests seek European integration and German and French governments thus support it. Our analysis 
predicts mixed national preferences on the EU bank resolution regime. On the one hand, governments sought limited delegation in terms of reinforced EU rules, a role for the Single Resolution Board and Fund to boost confidence in the possible resolution of European banks without contagion effects. On the other hand, governments were unwilling to enforce the necessary bank funding requirements to ensure that the EU bank resolution regime could function because most European-headquartered banks, constrained by long-standing business models and / or with an eye to profit margins, were opposed to efforts to reinforce capital and MREL rules.

While a number of EU member state governments sought to water down capital requirements and MREL, our analysis places emphasis on the relative importance of German and French government preferences. Four considerations lead us to this focus. First, in intergovernmental negotiations on EU policy, these two governments tend to weigh more heavily and largely shape policy outcomes (Moravscik, 1998; on Banking Union and the Single Resolution Mechanism specifically, Howarth and Quaglia, 2013b; 2014; Schild, 2018). Second, we focus on German preferences given the 'constrained' veto-power exercised by Germany in negotiations on the elements of Banking Union (Bulmer, 2014). The German government was able to block some elements of Banking Union. However, given the danger of Eurozone collapse, the German government had to accept some compromises which diverged significantly from its preferences. Third, we focus on French preferences because French governments were particularly active in promoting Banking Union and notably European-level support funds for banks (Howarth and Quaglia 2016). Fourth, we also focus upon German and French governments because of their varyingly aligned, divergent and competing preferences on the building blocks of 
the EU resolution rules which undermined the effectiveness of these rules in different ways. While Schild (2018) points to the major differences in German and French preferences on Banking Union which shaped negotiations and outcomes, on the building blocks of the EU resolution regime Franco-German differences were significantly less trenchant but still weakened these elements.

Our liberal intergovernmentalist analysis of the EU bank resolution regime contributes to three main bodies of academic literature. First, our analysis contributes to the emerging literature on the politics and political economy of Banking Union (Donnelly, 2014; Howarth and Quaglia, 2016, 2018, 2020; Schimmelfennig, 2016; Spendzharova, 2014) which feeds into the vast literature on monetary integration and the development of European economic governance (for example, Dyson and Featherstone, 1999; Moravscik, 1998; Walsh, 2000). Second, our liberal intergovernmentalist analysis contributes to the literature on German and French preferences on EU economic governance and on Banking Union in particular (Schäfer, 2016; Schild, 2018). By rooting national government preferences in the defence of powerful banking interests, our argument parallels but does not rely upon studies emphasizing the power of big banks in the move to and design of Banking Union (Culpepper and Tesche, 2020).

Third, our analysis adds to the literature on the structural deficiencies of bank resolution dominated by financial economists and legal scholars (Avgouleas and Goodhart, 2019; Gordon and Ringe, 2015; Tröger, 2019; Binder and Singh, 2016; Mayes, 2019). The political science literature on EU resolution rules to date focuses upon the creation of the Single Resolution Mechanism (Howarth and Quaglia, 2014; Asimakopoulos, 2018a) and 
on its problematic operation given political pressures (Donnelly and Asimakopoulos, 2019). Here we point exceptionally to fundamental weaknesses in the design of EU resolution rules given reliance on funding that is insufficiently available.

Other possible explanations of the inadequate EU bank resolution regime agreed can be considered. Neo-functionalism offers a potentially valid explanation for the move to Banking Union and more specifically the Single Resolution Mechanism: notably, functional spill-over from monetary integration and financial market integration (Howarth and Quaglia 2020). However, neo-functionalism offers no guidance to national government preferences on bank capital requirements and MREL which must be examined to explain the inadequacy of the EU bank resolution regime. The 'failing forward' analysis (Jones et al. 2016) combines the insights of neo-functionalism and intergovernmentalism to explain the move to Banking Union. Applying this analysis, the inadequacy of the EU resolution regime can be seen as part of a lowest common denominator bargain and a 'failing forward' process that only a serious crisis is likely to reinforce. However, the 'failing forward' analysis also fails to explain the distinct member state governments preferences on the building blocks that resulted in the inadequate resolution regime.

Other possible explanations of national, or specifically German and French, government preferences on bank resolution rules can be considered, including a constructivist focus on ideas (Schäfer, 2016). Ordoliberal ideas and the preoccupation with moral hazard shaped German policy on several elements of Banking Union (Schäfer, 2016). While opposition to government- or European-level funded bank bail-out has been a 
longstanding policy preference of German federal governments (Hardie and Howarth, 2009) - albeit left aside in the aftermath of the recent international financial crisis - the introduction of an EU-wide ban on government bail-outs has also been presented by German governments as a vital mechanism to ensure the adequate operation of EU competition policy and to undermine the moral hazard that the likelihood of bail-out creates, especially for the biggest banks. We demonstrate that such ideas work better with regard to German policy on some of the building blocks of a potentially effective EU resolution regime - specifically, the resolution funds required by the Bank Recovery and Resolution Directive - than on other elements - capital requirements and MREL. German moral hazard concerns also applied to the creation of a Single Resolution Fund with the aim of protecting German banks and taxpayers against future public bail-outs of banks.

\section{Explaining the ineffectiveness of EU bank resolution rules}

Bank resolution constitutes a sui generis legal construction in that it is an administrative procedure with insolvency-like effects. The European Central Bank (or the Board) is the first to signal that a bank is 'failing or likely to fail'. Then, the bank is liquidated under national insolvency laws unless the Board decides to resolve the bank at the European level on 'public interest' grounds - subject to the Commission's endorsement. In terms of resolution financing, private sector involvement is prioritized through the use of the bail-in tool (Conlon and Cotter, 2014; Goodhart and Avgouleas, 2019). Bail-in allows for resolution authorities to impose losses on shareholders and creditors through write-downs and conversion of debt to equity before using resolution or public funding. However, for bail-in to be enforceable, all EU banks need to meet MREL — that is, have sufficient 
capital and 'eligible' liabilities to absorb some losses. In addition to bail-in, the private sector involvement also occurs through the use of private 'insurance' funds: European and national resolution funds, national deposit guarantee schemes, and in certain countries sectoral or industry-wide institutional protection schemes.

The application of MREL to all EU-headquartered banks is a unique feature of the EU resolution regime. In the US, the total loss absorbing capacity (TLAC) standard — similar to MREL — only applies to global systemically important banks (FSB, 2018), whilst all other banks are only required to meet the minimum prudential requirements (Deslandes et al., 2019). This unique feature of the general application of MREL has been justified notably because of 'level playing field' / competition concerns of member state governments in the Single Market. Imposing MREL requirements on only a small number of very large banking groups would hit national banking systems differently because of varying levels of concentration. The highly concentrated Dutch system would be hit significantly more than less concentrated banking systems, as in Germany and Italy. Furthermore, large banking groups were concerned about the implications for their competitiveness in relation to smaller banks (interviews $3,5,6,8,10,11$ ). The same 'level playing field' concerns have resulted in the general application of Basel capital and liquidity guidelines to all EU banks regardless of size through capital requirements legislation.

Another reason for the decision to apply MREL to all banks is the fragmentation and limited capacity of resolution financing in the EU: resolution and deposit guarantee scheme funds differ between Eurozone and non-Eurozone countries (interviews 3, 5, 6, 
8, 10, 11). For Eurozone countries, resolution funds remain partly national and will become fully centralized under the Single Resolution Fund by 2024. Deposit guarantee schemes remain purely national and the establishment of the European Deposit Insurance Scheme (EDIS) appears unlikely given entrenched German opposition (Howarth and Quaglia, 2018).

It is, nonetheless, clear that banks do not require the same MREL. Thus, the uniform approach to legislation has been balanced by a case-by-case approach to enforcement. If the preferred strategy is liquidation then the required MREL needs to suffice only for loss-absorption (Board, 2019). If the preferred strategy is resolution, then there are two alternative scenarios: open-bank bail-in and transfer-based. Using bail-in as part of an open-bank resolution is intended to allow for the continuation of a bank's critical functions, such as deposit-taking and the provision of loans, whilst utilizing internal funds and liabilities to cover losses and recapitalize the institution. MREL needs to be higher in resolution than in liquidation so as to include sufficient MREL for recapitalization. Transfer-based resolution aims to preserve a bank's critical functions by transferring them to another entity with the use of the sale of business, separation of assets, and the establishment of a bridge institution. Here, the ultimate goal of resolution authorities is to sell partly or entirely the resolved entity to a buyer. Given the lower reliance of this strategy on bail-in, MREL for recapitalization is set at lower levels than in an open-bank bail-in scenario (Board, 2019).

Collective industry financing remains limited and attached to strict conditions. Resolution financing — provided by the Single Resolution Fund — requires that bail-in applies to at 
least eight per cent of a bank's total liabilities and own funds before the Fund's use. This 8 per cent requirement is in practical terms significantly higher given the fact that the resolution framework appears to not allow the incorporation of historical losses - that is, losses that occurred prior to the execution of resolution tools - in the calculation. However, the use of the Fund cannot exceed an amount equal to five per cent of the bank's total liabilities and own funds even if such resources exist. Thus, any additional financing needs should be covered through additional bail-in, which may entail significant contagion risks and, notably, depositor panic.

Deposit guarantee schemes can contribute in resolution only in some countries (Belgium, Denmark, Finland, Greece, Ireland, Italy, Luxembourg, Lithuania, Malta and Poland, and the UK), while all the others have chosen not to transpose this option into national law (CEPS, 2019). However, even when transposed, the contribution of deposit guarantee schemes in resolution remains limited. In particular, this contribution is capped at the lower of either the loss it would have suffered if it had paid out the covered deposits in a liquidation scenario (net of recoveries during insolvency), or fifty per cent if its target level.

We argue that the abovementioned MREL-based regulatory framework will not effectively support either resolution scenario - open-bank bail-in or transfer strategy resolution - for small and mid-sized retail banks and thus pushes them into national liquidation where the bail-in thresholds to access external financing of the Bank Recovery and Resolution Directive and the Single Resolution Mechanism Regulation do not apply. We support this claim by outlining the three mentioned resolution scenarios. 


\section{Open-bank bail-in}

The enforcement of open-bank bail-in is unlikely for two main reasons. First, an openbank bail-in strategy requires that the bank possesses sufficient MREL both for lossabsorption and recapitalization. However, EU-headquartered smaller and medium-sized retail banks on average hold either less MREL than large universal banks or of poorer quality - that is comprising uncovered deposits as well — and are less likely to support a bail-in — in 2016, retail banks held an average MREL of only 28 per cent per cent of risk-weighted assets, while large universal banks held an average of 37.9 (EBA, 2016, 2017). For larger banks the effective MREL requirements are manageable when compared to the total size of their balance sheets, given that the calculation of MREL depends on the asset density of their balance sheets. Smaller retail — including savings and cooperative (alternative) — banks find it extremely expensive to issue these MREL amounts since most of them are not listed on stock exchanges and do not in many cases issue unsecured debt, and thus, interest rates offered to them are higher compared to what is offered to bigger universal banks (Asimakopoulos, 2019b; interview 10). Moreover, MREL requirements, in general, are likely to be underestimated for smaller retail banks compared to universal banks given the lack of adequate information on retail banks' historical losses (interviews 3, 5, 6, 8, 11; Stiefmüller, 2016). Imposing additional MREL liabilities threatens the commercial viability of retail banks, which generally operate with low-risk profile. The alternative would be for retail banks to change their business model — which focuses on providing traditional intermediary functions to the real economy and invest in higher-risk assets. 


\section{Transfer strategies}

Transfer strategies do not rely primarily on bail-in but instead on the sale of business, the separation of assets or the establishment of a bridge institution. The enforcement of a transfer strategy entails two scenarios: either a purchaser is found at the point of resolution or the resolution authority sets up a bridge institution until a purchaser is found. In the first scenario, recourse to extensive bail-in and resolution funding can be avoided, while in the second scenario, bail-in can be used to cover the costs inherent in the operation of the bridge institution and the subsequent transfer. However, the extensive use of bail-in in effect destroys the bank's relationship with its creditors and lowers its investment value, thus reducing the chances for a successful execution of transfer-based resolution.

\section{Liquidation}

When neither resolution strategies are enforceable, national-level liquidation is the last alternative. Liquidation can be either court-based (corporate) or administrative (bankspecific). Court-based liquidation involves bringing a business to an end and distributing its assets to claimants in accordance with their seniority. It involves the use of deposit guarantee schemes to reimburse covered depositors — up to at least $€ 100,000$ — as required by the EU's Deposit Guarantee Scheme Directive of 2014. However, the attempt to enforce liquidation in this sense generates three main problems. First, most national deposit guarantee schemes lack the funds to reimburse depositors. According to the 2014 Directive, the target that most national schemes need to meet stands at 0.8 per cent of total deposits. However, many national schemes do not collect these funds ex ante and the need to replenish scheme funds immediately could put many banks under financial pressure, especially during a period of general financial instability (EBA, 2019). Second, 
even assuming that scheme funding would suffice to reimburse covered depositors, the impact upon the real economy from imposed losses — a haircut — on uncovered deposits could be immense — depending upon the size of the bank in question. The political cost of a haircut could also be significant (interviews 3, 7, 8, 10; Donnelly and Asimakopoulos 2019). Third, removing a bank from the market would terminate its critical functions to the real economy, such as deposit-taking and credit provision, the very functions that resolution is intended to preserve. Therefore, court-based insolvency can be justified only for very small banks.

The alternative in some jurisdictions is administrative liquidation which allows the use of transfer tools, such as separation of assets, sale of the good assets to a buyer and liquidation of the remaining bad assets (Deslandes et al., 2019). Losses are covered through limited bail-in — so-called 'burden-sharing' — coupled with the use of liquidation aid under EU state aid rules and, potentially, funds from national deposit guarantee schemes. However, once out of the scope of EU resolution rules, national authorities could indeed circumvent resolution through the application of a resolutionlike administrative liquidation, as was the case with the Veneto banks (Asimakopoulos, 2018b; Donnelly and Asimakopoulos, 2019).

Overall, the enforceability of the EU resolution framework boils down to bail-in and hence MREL. In this context, bail-in and collective resolution financing are strongly interdependent; the stronger the reliance on collective financing the weaker the need for extensive bail-in, and vice versa. Therefore, bail-in and collective resolution financing need to be assessed together. In practical terms, the thresholds placed on the use of the 
Single Resolution Fund and deposit guarantee schemes in resolution make reliance on bail-in and MREL vital to the effectiveness of resolution. Whilst this policy option may prove effective for larger universal banks, this may not be the case for small and midsized retail banks, which might not always be able to issue sufficient MREL and which may be unable to meet the 8 per cent bail-in thresholds without impacting depositors. Therefore, the Single Resolution Board, acknowledging the constraints of the resolution framework, has the incentive to opt for a negative public interest assessment in the case of failure of small and mid-sized banks and lead such a bank into liquidation. In turn, in liquidation, the limited capacity of deposit guarantee schemes may result in the use of bail-outs in the form of liquidation aid — which is precisely what EU resolution rules were created to avoid.

\section{National government and bank preferences on bank capital}

Bank capital and MREL share common characteristics. MREL requires that liabilities subject to bail-in need to be as subordinated as possible to facilitate bail-in and minimize litigation risks. In this context, the most subordinated form of MREL is equity. Given though the higher cost of equity for banks, MREL can also consist of unsecured debt. Therefore, MREL-eligible debt supplements equity in order to ensure that losses can be covered and banks can be recapitalized with own funds and eligible liabilities. MREL also enhances liquidity for banks since MREL-eligible liabilities are long term in nature in order to mitigate the role-over risk in debt issuances.

Our liberal intergovernmentalist analysis explains government preferences on bank capital requirements in terms of the interests of nationally-headquartered banks. Bank 
preferences on capital requirements reflect their activities which in turn are shaped by the structure of national banking and financial systems (Howarth and Quaglia, 2013a). In December 2010, the Basel Committee of Bank Supervisors agreed upon the Basel III guidelines on bank capital. These guidelines were only to apply to large global systemically important banks funded by equity finance (hence the emphasis on common equities in core tier 1 capital), whereas many banks in the EU relied on other funding sources. Thus, the Basel Committee warned about the differentiated effects of Basel III across countries (BCBS, 2010). Large French universal banks - which dominated the national banking system - were better capitalized because, on average, they relied more on equity finance in relative terms than banks in most continental European countries. ${ }^{1}$ Many banks on the continent such as the German savings and cooperative banks lacked equity finance which created difficulties for the adoption of the Basel III accord into EU capital requirements legislation (IMF 2011). The German government in particular had good reasons to oppose the rigid tightening of capital requirements. The data on French banks suggest their strong position but the double counting of insurance subsidiaries which Basel III recommends banning — inflates the tier 1 capital ratio for the largest French banks significantly (IMF 2011, 2012).

The close alignment of German and French bank, bank association and government (ministry of finance) preferences on capital requirements can be seen most clearly in their

\footnotetext{
${ }^{1}$ In terms of bank equity as a percentage of total assets, French banks had on average 3.8, 4.91 and 5.07 per cent for 2008-10 (ECB Statistical data warehouse. Domestic banking group and stand-alone banks only). The Basel and EU capital requirements directive target was a core tier 1 ratio of 4.5 per cent or 7 per cent with the 'capital conservation buffer' from 2019. German banks had on average only 2.93, 3.76 and 3.88 per cent for 2008-10. In the five European Banking Authority stress tests conducted in 2011, 2012, 2014, 2016 and 2018, French banks were on average at or near to Basel III targets in most years even under adverse scenarios. German banks fell consistently short in the adverse scenario. (EBA, https://eba.europa.eu/risk-analysis-and-data/eu-wide-stress-testing.)
} 
comments on the European Commission's public consultation on the EU's amended Capital Requirements Directive of 2013 (CRDIV). ${ }^{2}$ In parallel with bank and bank association efforts, the German and French governments lobbied to water down the implementation of Basel III in EU and national legislation. The peak association representing all German banks sought a grandfathering clause on Basel III capital guidelines of 'at least 30 years' which forced the German government to push for a significant modification to the guidelines in their transposition into EU law (Zentraler Kreditausschuss, 2010, p. 3). To meet German demands, the 2013 directive allows for one form of capital which many alternative banks previously relied upon to meet capital requirements - specifically hybrids: that is, capital which has some features of both debt and equity and notably 'silent participations' (long maturity loans from governments). The French government (with German support) also lobbied to prevent the implementation of Basel III provisions banning the double counting of capital held by the insurance subsidiaries of banks. It was estimated that the elimination of double counting would result in French banks losing a total of 28.9 per cent of their tier 1 capital, preventing several from meeting the Capital Requirements Directive's six per cent threshold and all from meeting the 8.5 per cent threshold (with the capital conservation buffer in place from 2019) (IMF, 2011). A ban would have hit the three large French commercial banks particularly hard because of the longstanding feature of the French banking system of bancassurance - also found in a number of other EU member states (FBF, 2010).

\footnotetext{
2 The authors have accessed the official comments from the following bodies on Basel III and the amendment to the EU capital requirements directive: French Banking Federation (FBF, 2010a, 2010b); the banks BNP Paribas (2010), Crédit Agricole, BPCE Group and Crédit Mutuel (2010); and the French Ministry of Finance, Bank of France and the Secretary General of the Prudential Control Authority (2010); the Zentraler Kreditausschus (2010); Deutsche Bank (2010); and the German Ministry of Finance (2010). All these documents can be obtained from the authors.
} 
While German governments had strong preferences on collective industry resolution financing, their preferences on MREL were less clear-cut, due in large part to the diversity of the German banking system (Asimakopoulos, 2018a). As noted above, large banks had few concerns in meeting MREL given their funding model (see also Deutsche Bank, 2010b; Zentraler Kreditausschus, 2010b). However, alternative banks that participated in institutional protection schemes were exempted from MREL requirements because these schemes ensured their resolvability. Thus, the German government was indifferent as to the implementation of MREL in Germany. At the same time, given German government reluctance to ensure credible collective industry financing at the European level, there was a strong interest to require MREL for all European banks.

\section{National government and bank preferences on deposit insurance}

German, French and other national governments pushed for EU legislation that failed to ensure the adequate funding of national deposit guarantee schemes - a failure that undermined efforts to agree upon both an inter-fund transfer mechanism and a European Deposit Insurance Scheme. Inadequately funded deposit guarantee schemes and the absence of a transfer mechanism fundamentally undermined the applicability of EU rules on bail-in. In developing our liberal intergovernmentalist analysis, we explain the absence of sufficient deposit insurance funds in the large majority of EU member states in terms of government and bank preferences and the structure of national banking systems.

In 1994, the EU adopted the first Deposit Guarantee Scheme Directive, which was based on minimum harmonization. However, member state implementation of the directive was 
largely undertaken in ways that most national banks could accept and were suitable to national banking systems and pre-existing national deposit guarantee schemes (see Garcia and Prast, 2003; Demirgü-Kunt et al., 2006). The principal difference, among the EU member states with the largest banking systems, was that only Germany had in place institutional protection schemes (also covering deposit insurance) which had significant ex ante funds - that is, funds paid in advance. None of the other member states with large banking systems had deposit insurance schemes with significant ex ante funds. Most relied on ex post funds, to be collected from other banks when one faced difficulties.

In Germany, separate deposit guarantee schemes and institutional protection schemes were set up by commercial, savings, cooperative and other public law banks. The requirement of ex ante bank contributions in large part reflected the small size of most alternative banks where such in advance contributions helped to build confidence in the deposit guarantee, whereas ex post contributions might be financially unmanageable (Bülbül et al., 2013; IMF, 2009, 2011). The coverage provided for deposits was $€ 100,000$. Savings and cooperative banks did not participate in the statutory national deposit guarantee schemes except if the national supervisor (BaFin) decided that their own schemes failed to fulfil required specific conditions. The ratio of retail deposits protected under the institutional protection schemes of savings and cooperative banks was even higher than in the private sector (IMF, 2011). In addition to their opposition to any transfer system among EU member state deposit guarantee schemes, German banking associations and individual banks feared that a European Deposit Insurance Scheme would impinge upon their sectoral institutional protection schemes (Kaiser, 2012; interview 9). Moreover, German banks with their well-funded ex ante schemes, feared 
that they would likely become net contributors to a European Deposit Insurance Scheme — thus bailing out depositors in other Eurozone member states given the widespread reliance on ex post funded deposit guarantee schemes.

The French deposit guarantee scheme reflected the highly concentrated French banking system, dominated by five large banks, principally in terms of its 'pay-box' scheme and the limited amount of ex ante funds. Banks paid a yearly fee to the guarantee fund based on the amount of deposits covered in each bank by the fund, and exceptional contributions if the fund was depleted due to pay-outs. At the end of 2019 , the fund held almost $€ 4.5$ billion or 0.37 per cent of total deposits up from 0.21 per cent in 2010 but well below target levels set in the 2014 directive (IMF, 2012; EBA, 2019). The design of the French deposit guarantee scheme was defended on the grounds that bank resolution in France involved the required sale of assets and liabilities that would normally cover the reimbursement of depositors (FGDR, 2019). This requirement of selling off assets was a reflection of the large size of the biggest French banks which dominated the national banking system and were better positioned to sell off assets, than, for example, small German banks (Howarth, 2013).

As the 1994 Deposit Guarantee Scheme Directive was based on minimum harmonization, national deposit guarantee schemes continued to differ in several important respects, such as the definition of eligible deposits, the level of cover, the types of funding mechanism and the calculation of bank contributions. The international financial crisis and then the Eurozone sovereign debt crisis encouraged the Commission to propose legislative changes to the 1994 directive. In July 2010, the Commission put forward a legislative 
proposal to amend the Deposit Guarantee Scheme Directive with a view to promoting the 'harmonization and simplification of protected deposits, a faster pay-out, and an improved financing of schemes' (Commission, 2010, p. 5). The Commission's push in favour of ex ante funding for deposit guarantee schemes stemmed from widespread economic opinion focused on the dangers of relying on bank contributions during difficult economic times (FSB, 2012; IMF, 2013).

Opponents, including the French government, argued that ex ante payments would hit banks hard during a difficult period and sought lengthy transition periods to build up funds (IMF, 2013; Howarth and Quaglia, 2017; interview 2). The initial Commission's proposal had been 1.5 per cent of eligible deposits raised over a ten-year transition period but French and other government opposition lowered this to 0.8 per cent. Moreover, with Commission approval, member states could set a target level to as low as 0.5 per cent if the characteristics of the banking sector - for example, the concentration of most assets in a few banks - made it unlikely that banks would be liquidated using the deposit guarantee schemes (Commission, 2014). This was a concession to France, the UK and the Netherlands with their highly concentrated banking systems (Bloomberg, 18 December 2013; interview 2). In 2014, schemes in about half of the member states had already reached the 0.8 per cent target level (or were above or relatively close to it) (Commission, 2014). However, the French deposit guarantee scheme was far below the 0.5 per cent level.

While the German government approved of higher ex ante funding requirements, it opposed the Commission's harmonization efforts to the extent that they menaced the 
country's self-regulated voluntary deposit guarantee schemes and institutional protection schemes (Moloney, 2011). Most German banks also feared that they would be forced to establish an additional fund based specifically on ensuring deposits (Donnelly, 2014). The revised 2014 Deposit Guarantee Scheme Directive gave the existing institutional protection schemes the choice of being officially recognized as a deposit guarantee scheme (and thus to be subject to all the provisions of the directive). If they continued their operation as purely institutional protection schemes, they would not be subject to the directive, but member banks would also have to contribute to an official deposit guarantee scheme. In order to appease German alternative banks, their lower risk linked to mutual protection could be taken into account when risk-based contributions to DGS were calculated.

\section{Conclusion}

The liberal intergovernmentalist analysis of this paper demonstrates that German, French and most other EU member state governments accepted legislation on EU bank capital requirements and resolution rules on MREL and resolution financing that did not significantly threaten the business models of different banks — from big universal banks to smaller alternative banks. The German and French governments moved to water down the application of Basel III capital guidelines — notably by allowing silent participations. The governments of countries dominated by very large banks — notably France, the UK and the Netherlands - were indifferent to Commission efforts to increase minimum bailin requirements and thus MREL. The German government largely shared this indifference, at least insofar as the impact on its own banking system was concerned. The 
Italian government and a number of others moved to dilute efforts to increase MREL due to the retail business models that are prevalent in their jurisdictions.

In this paper, we have demonstrated that the fixed bail-in requirements and relatively high MREL found in the Bank Recovery and Resolution Directive and the Single Resolution Mechanism Regulation are unlikely to support effectively either resolution scenario based on open-bank bail-in or based on transfer strategies — thus pushing banks into national liquidation. The reliance almost exclusively on MREL rather than offsetting MREL requirements with sufficient collective financing in national and EU level resolution funds fundamentally undermines the credibility of the EU's bank resolution regime, ultimately leading to government funded bail-outs instead of private sector bailins. Although the EU bank resolution framework relies on MREL to resolve banks, issuing MREL is very difficult for many retail banks. MREL must therefore be seen as a 'trap door' that renders the EU resolution regime inherently defective. Recent efforts in the revised Bank Recovery and Resolution Directive and Single Resolution Mechanism Regulation from 2019 to recalibrate MREL by taking into consideration different banking models - such as cooperatives — is a step in the right direction (SRB, 2020). However, the revisions adopted fail to address effectively the fundamental issues of the same fixed bail-in thresholds, the lack of sufficient MREL and the problematic focus on MREL in the EU resolution regime.

Thus, a central element of European Banking Union is found lacking. In the meantime, a number of national resolution funds have not been filled to schedule and the Single Resolution Fund - even if it reaches the planned $€ 50$ billion figure - is likely 
insufficient to resolve large European banks and thus boost confidence in the capacity of the EU resolution regime to avoid a systemic crisis (Mayes, 2018). However, the aim of our contribution is to demonstrate that the likelihood that these bank-provided resolution funds can ever be used to support resolution is limited because too many EU banks are unable to assume their share of the losses, prior to bail-in, thus preventing resolution. The EU resolution regime would have to be redesigned to ensure the automatic use of resolution funds and fundamental German government opposition means this is unlikely.

Our liberal intergovernmental analysis aligns with a number of other studies which point to messy Franco-German compromises on the core elements of Banking Union (Schild, 2018) and thus deficiencies in the design of Banking Union (Goodhart and Avgouleas, 2019; Mayes, 2018). Our analysis supports claims made by a number of scholars pointing to the importance of banking system structures in shaping government preferences on both the building blocks and core elements of Banking Union (Howarth and Quaglia, 2018) and to the immense power of banks in shaping national preferences and the outcomes on Banking Union (Culpepper and Tesche, 2020). Moreover, like the 'failing forward' thesis (Jones et al., 2016), we demonstrate the deficiencies of Banking Union which would only be addressed — and only in part — in the context of a future systemic banking crisis and worsening public debt situation in which the capacity of national governments to bail-out banks is sorely tested. The macro-economic effects of the Covid19 pandemic might well lead to such a crisis.

EU resolution rules were officially adopted to diminish the political pressures imposed upon national governments to rescue failing banks and thus bolster the stability of 
national banking systems. Fixed bail-in thresholds before accessing resolution funding and inadequate MREL levels undermine the efficacy of these resolution rules. Thus, the preferences of German, French and other EU governments on capital requirements, MREL and deposit insurance resulted in an EU resolution regime and a Banking Union that must be described as stillborn. The micro-economic interests of national banks trumped the macro-prudential stability concerns of governments and the 'public interest'.

\section{References}

\section{Laws}

Bank Recovery and Resolution Directive, Directive 2014/59/EU of the European Parliament and of the Council of 15 May 2014 establishing a framework for the recovery and resolution of credit institutions and investment firms.

Capital Requirements Directive IV , Directive 2013/36/EU of the European Parliament and of the Council of 26 June 2013 on access to the activity of credit institutions and the prudential supervision of credit institutions and investment firms.

Capital Requirements Regulation, Regulation (EU) No575/2013 of the European Parliament and of the Council of 26 June 2013 on prudential requirements for credit institutions and investment firms.

Deposit Guarantee Schemes Directive, Directive 2014/49/EU of the European Parliament and of the Council of 16 April 2014 on deposit guarantee schemes. 
Single Resolution Mechanism Regulation, Regulation (EU) No 806/2014 of the European Parliament and of the Council of 15 July 2014 establishing uniform rules and a uniform procedure for the resolution of credit institutions and certain investment firms in the framework of a Single Resolution Mechanism and a Single Resolution Fund.

Single Supervisory Mechanism Regulation, Council Regulation (EU) No 1024/2013 of 15 October 2013 conferring specific tasks on the European Central Bank concerning policies relating to the prudential supervision of credit institutions.

\section{References}

Asimakopoulos, I. (2018a) 'International Law as a Negotiation Tool in Banking Union: the case of the Single Resolution Fund'. Journal of Economic Policy Reform, 21(2), 118131.

Asimakopoulos, I. (2018b) 'The Veneto Banks Resolution: It Shall Be Called "Liquidation"'. European Company Law, 15, 156-162.

Asimakopoulos, I. (2019a) 'Making Retail Banks Resolvable'. European Banking Institute Working Paper Series, doi: 10.2139/ssrn.3471187.

Asimakopoulos, I. (2019b) 'The Single Resolution Board as a New Form of Economic Governance'. In Hofmann, H., Pantazatou, K., Zaccaroni, G. (eds), The Metamorphosis 
of the European Economic Constitution, Cheltenham, UK: Edward Elgar Publishing Ltd., 279-300.

Avgouleas, E., Goodhart, C. and Schoenmaker, D. (2013) 'Bank Resolution Plans as a catalyst for global financial reform'. Journal of Financial Stability 9(2), 210-219.

Ayadi, R. (2019) Banking Business Models: Definition, Analytical Framework and Financial Stability Assessment. Palgrave Macmillan Studies in Banking and Financial Institutions.

BCBS (2010) 'Assessing the macroeconomic impact of the transition to stronger capital and liquidity requirements: final report', 17 December.

Bierens, B. (2019) 'The Governance of Banks and the Requirement of Resolvability: a Fundamental Change in Perspective?'. In Busch D, Ferrarini G, van Solinge G (eds). Governance of Financial Institutions, Chapter 4, Oxford: Oxford University Press.

Binder, J and Singh, D., eds., Bank resolution: the European regime, Oxford: Oxford University Press.

BNP Paribas (2010) 'BNP Paribas Comments to Commission Staff Working Document, CRDIV', 16 April. 
Bülbül, D., Schmidt, R., Schüwer, U. (2013) 'Savings Banks and Cooperatives in Europe'. White Paper No. 5. SAFE, Frankfurt. URL: http://safefrankfurt.de/uploads/media/Schmidt_Buelbuel_Schuewer_Savings_Banks_and_Cooper ative_Banks_in_Europe.pdf

Bulmer, S, (2014) 'Germany and the Eurozone Crisis: Between Hegemony and Domestic Politics'. West European Politics, 37(6), 1244-263.

CEPS (2019) 'Options and national discretions under the Deposit Guarantee Scheme Directive and their treatment in the context of a European Deposit Insurance Scheme FINAL REPORT', November.

Commission (European Commission) (2010) 'Proposal for a Directive on Deposit Guarantee Schemes' [recast]. COM/2010/0368 final, 12 July, http://eurlex.europa.eu/LexUriServ/LexUriServ.do?uri=COM:2010:0368:FIN:EN:PDF.

Commission (European Commission) (2012) 'Impact Assessment of the BRRD Proposal'.

Commission (European Commission) (2014) 'Deposit Guarantee Schemes-Frequently Asked Questions'. URL: http://europa.eu/rapid/press-release_MEMO-14296_en.htm?locale=en.

Conlon, T. and Cotter, J. (2014) 'Anatomy of a bail-in'. Journal of Financial Stability 15(C), 257-263. 
Crédit Agricole, BPCE Group and Crédit Mutuel (2010) 'European Commission's consultation paper on CRDIV: Response of the Crédit Agricole, the BPCE Group (Caisse d'Epargne and Banques Populaires) and Crédit Mutuel, April.

Culpepper, P. and Tesche, T. (2020) 'Death in Veneto? European banking union and the structural power of large banks'. Journal of Economic Policy Reform, Early View, doi.org/10.1080/17487870.2020.1722125

Deeg, R. (1999) Finance Capitalism Unveiled: Banks and the German Political Economy. Ann Arbor: University of Michigan Press.

Demirgü-Kunt, A., Kane, E. J., and Laeven, L. (2006) 'Deposit Insurance Design and Implementation: Policy lessons from Research and Practice', World Bank Policy Research Working Paper Series, June.

Deslandes, J., Dias, C. and Magnus, M. (2019) 'Liquidation of Banks: Towards an 'FDIC' for the Banking Union?'. European Parliament In-depth Analysis URL: http://www.europarl.europa.eu/RegData/etudes/IDAN/2019/634385/IPOL_IDA(2019)6 34385_EN.pdf.

Deutsche Bank (2010a) 'Detailed comments on CP 164', 16 April 2010. 
Deutsche Bank (2010b) 'Response to BCBS Consultative Document 174: Proposal to ensure the loss absorbency of regulatory capital at the point of non-viability', 1 October.

Donnelly, S. (2014) 'Power Politics and the Undersupply of Financial Stability in Europe'. Review of International Political Economy, 21(4), 980-1005.

Donnelly, S. and Asimakopoulos, I. (2020) 'Bending and Breaking the Single Resolution Mechanism: the case of Italy'. Journal of Common Market Studies, 58(4), 856-871.

Dyson, K. and Featherstone, K. (1999) The Road to Maastricht. Oxford University Press.

EBA (European Banking Authority) (2016) Final Report on MREL. URL: https://eba.europa.eu/sites/default/documents/files/documents/10180/1695288/be1ffc3ee966-4bfe-a5fc-5e80e1873726/EBA\%20Final\%20MREL\%20Report\%20\%28EBA-Op2016-21\%29.pdf?retry=1.

EBA (2017) Quantitative Update of the EBA MREL Report. URL: https://eba.europa.eu/sites/default/documents/files/documents/10180/1720738/377f556f $-65 c e-4328-b e 7 e-$ c3e6b9237416/Quantitative\%20update\%20of\%20the\%20EBA\%20MREL\%20Report.p df?retry $=1$.

EBA (2019) Data on Deposit Guarantee Schemes. URL: https://eba.europa.eu/ebaupdates-data-on-deposit-guarantee-schemes-across-the-eu. 
Epstein, R. and Rhodes, M. (2016) 'The Political Dynamics behind Europe's New Banking Union'. West European Politics, 39(3), 415-37.

FGDR (Fonds de garantie des dépôts et de résolution) (2019) Annual Report 2018. Paris URL:

https://www.garantiedesdepots.fr/sites/default/files/fgdr_rapport_annuel_2018_uk.pdf

FSB (Financial Stability Board) (2012) FSB Publishes Peer Review on Deposit Insurance Systems. Press release, Ref no: 13/2012. 8 February, https://www.fsb.org/wpcontent/uploads/r_120208.pdf.

FSB (Financial Stability Board) (2018) List of Global Systemically Important Banks. URL: https://www.fsb.org/2018/11/2018-list-of-global-systemically-important-banks-gsibs/.

FBF (French Banking Federation) (2010a) 'FBF comments on the public consultation on the Capital Requirements Directive ('CRDIV'), 21 April.

French Banking Federation (2010b) 'FBF comments on the BCBS Consultative Paper no. 174 on loss absorbency of regulatory capital at the point of non-viability', 1 October.

French Ministry of Finance, Bank of France and the Secretary General of the Prudential Control Authority (2010) ' European Commission's consultation paper on CRDIV: 
Réponse du Ministère de l'Economie, de la Banque de France et du Secrétairat Général de l'Autorité de Contrôle Prudentiel'.

Garcia, G. and Prast, H. (2003) 'Depositor and Investor Protection in the EU and the Netherlands: A Brief History'. Journal of European Economic History, 32(3), 307-348.

German Ministry of Finance (2010) Responses to the Commission's Working Document 'Conclustation regarding further possible changes to the Capital Requirements Directive (CRD), 15 April, VII B 3 a - WK 5611/09/10005, 2010/0288785.

Goodhart, C. and Avgouleas, E. (2016) 'Critical reflections on bank bail-ins'. In Serrano, A.S. (ed), The Reform of International Economic Governance, London: Routledge, 5782.

Goodhart, C. and Avgouleas, E. (2019) 'Resolution 10 Years from the Global Financial Crisis: A Systematic Reappraisal'. LUISS Working Paper. URL: https://sep.luiss.it/research/working-papers/2019/05/13/e-avgouleas-and-c-goodhartbank-resolution-10-years-global-financ.

Gordon, J., Ringe, W. (2015) 'Bank Resolution in the European Banking Union: A Transatlantic Perspective on What It Would Take'. Columbia Law Review 115, 12971369. 
Hardie, I. and Howarth, D. (2009) 'Die Krise but Not La Crise', Journal of Common Market Studies, 47(5), 1019-1039.

Howarth, D. (2013) 'France and the International Financial Crisis: the Legacy of Stateled Finance'. Governance, 26(3), 369-395.

Howarth, D., Quaglia, L. (2013a) 'Banking on Stability: The Political Economy of New Capital Requirements in the European Union'. Journal of European Integration 35(3), $333-346$

Howarth, D., Quaglia, L. (2013b) 'Banking Union as Holy Grail: Rebuilding the Single Market in Financial Services, Stabilizing Europe's Banks and "Completing" Economic and Monetary Union'. Journal of Common Market Studies, 51(1) 103-123.

Howarth, D., Quaglia, L. (2014) 'The Steep Road to European Banking Union: Constructing the Single Resolution Mechanism'. Journal of Common Market Studies, $52(1), 125-140$

Howarth, D., Quaglia, L. (2017) 'The difficult construction of a European Deposit Insurance Scheme: a step too far in Banking Union?'. Journal of Economic Policy Reform 21(3), 190-209.

Howarth, D., Quaglia, L. (2020) 'One Money, Two Markets?: EMU at Twenty and Financial Market Integration'. Journal of European Integration, 42(3), 433-448. 
IMF (International Monetary Fund) (2009) 'European Commission Consultation Review of Directive 94/19/EC on Deposit Guarantee Schemes (DGS) IMF Staff Position', 12 August, Washington: IMF; available at https://www.imf.org/external/np/eur/2009/081209.pdf

IMF (International Monetary Fund) (2011) 'Germany: Technical Note on Crisis Management Arrangements'. IMF Country Report No. 11/368, December. URL: https://www.imf.org/external/pubs/ft/scr/2011/cr11368.pdf.

IMF (International Monetary Fund) (2012) 'France: Financial Stability Assessment'. IMF Country Report No. 12/137, December. URL: https://www.imf.org/external/pubs/ft/scr/2012/cr12341.pdf, accessed on 2 February 2017.

IMF (International Monetary Fund) (2013) 'Technical Note on Deposit Insurance. Financial Sector Assessment Programme, European Union'. IMF Country Report No. 13/66, March. URL: https://www.imf.org/external/pubs/ft/scr/2012/cr12341.pdf.

Jones, E., Keleman, R.D., and Meunier, S. (2016) 'Failing Forward? The Euro Crisis and the Incomplete Nature of European Integration'. Comparative Political Studies, 49(7), $1010-1034$. 
Kaiser, S. (2012) 'Anzeigeaktion gegen die Bankenunion: Kampf um die deutschen Spargroschen'. Spiegel Online, September 13. Accessed October 15, 2017. http://www.spiegel.de/wirtschaft/soziales/sparkassen-und-volksbanken-kaempfengegen-bankenunion-a-855706.html

Mayes, D. (2018) 'The Problem of Untried Systems'. Journal of Economic Policy Review 21(3), 178-89.

Mesnard, B., Margerit, A., Magnus, M. (2017) 'The resolution of Banco Popular'. European Parliament Briefing URL: http://www.europarl.europa.eu/RegData/etudes/BRIE/2017/602093/IPOL_BRI(2017)60 2093_EN.pdf.

Moloney, N. (2011) 'The European Securities and Markets Authority and Institutional Design for the EU Financial Market - A Tale of Two Competences: Part (1) RuleMaking'. European Business Organization Law Review 12(1), 41-86.

Moravscik, A. (1998) Choice for Europe. London: UCL Press.

Schäfer, D. (2016) 'A Banking Union of Ideas? The Impact of Ordoliberalism and the Vicious Circle on the EU Banking Union'. Journal of Common Market Studies, 54(4), 961-980. 
Schild, J. (2018) 'Germany and France at cross purposes: the case of Banking Union'. Journal of Economic Policy Reform 21(2), 102-117.

Schimmelfennig, F. (2016) 'A Differentiated Leap Forward: Spillover, Path dependency, and Graded Membership in European Banking Regulation'. West European Politics 39(3), 483-502.

Single Resolution Board (SRB) (2020) 'Minimum Requirement for own funds and Eligible Liabilities (MREL)'; available at: https://srb.europa.eu/en/content/mrel

Spendzharova, A. (2014) 'Banking union under construction: The impact of foreign ownership and domestic bank internationalization on European Union member-states' regulatory preferences in banking supervision'. Review of International Political Economy, 21(4), 949-979.

SRB (Single Resolution Board) (2019) MREL Policy Report 2018 - second wave. URL: https://srb.europa.eu/en/node/708.

Stiefmüller, C. (2016) ' TLAC/MREL: Making failure possible?' Finance Watch Policy Brief, March, Brussels: Finance Watch, available at https://www.finance-watch.org/wpcontent/uploads/2018/08/Finance-Watch-Policy-Brief-March-2016.pdf. 
Tröger, T. (2019) 'Why MREL won't help much: minimum requirements for bail-in capital as an insufficient remedy for defunct private sector involvement under the European bank resolution framework'. Journal of Banking Regulation, 21, 64-81.

Walsh, J. (2000) European Monetary Integration and Domestic Politics; Britain, France and Italy. London: Lynner Rienner.

Zentraler Kreditausschus (2010a) 'Arbeitspapier der Dienststellen der Europäischen Kommission $\mathrm{zu}$ möglichen zusätzlichen Änderungen der Banken- under Kapitaladäquanzrichtlinie ('CRD'), 16 April.

Zentraler Kreditausschus (2010b) 'Comment by the Zentraler Kreditausschuss on the Basel Committee', Consultative Document 'Proposal to ensure the loss absorbency of regulatory capital at the point of non-viability'.

\section{Interviews (officials working on bank resolution)}

Interview 1: Bank of England, 18 March 2016.

Interview 2: Bank of France, 13 December 2017, Paris.

Interview 3: Spanish Ministry of Finance, 10 November 2018, Madrid.

Interview 4: Italian Ministry of Finance, 21 February 2019, Frankfurt.

Interview 5: German Ministry of Finance, 25 April 2019, Berlin.

Interview 6: EU Commission, 8 June 2017, by Skype.

Interview 7: EU Commission, 8 June 2017, by Skype. 
Interview 8: ECB, 14 June 2019, Frankfurt.

Interview 9: German Savings Bank Association, 14 June 2019, Frankfurt.

Interview 10: Portuguese Ministry of Finance, 5 July 2019, Lisbon.

Interview 11: ECB, 25 July 2019, Milan.

Interview 12: EU Commission, 28 October 2019, Berlin. 